\title{
Customer relationship management activities in e-banking: the case of Iranian banks
}

\author{
Abbas Keramati* \\ Industrial Engineering Department, \\ University of Tehran, \\ P.O. Box 11155-4563, Tehran, Iran \\ E-mail: keramati@ut.ac.ir \\ *Corresponding author
}

\author{
M. Farshid and E. Salehi-Sangari \\ Industrial Marketing and E-commerce Division, \\ Luleå University of Technology, \\ Luleå, 97187 Sweden \\ E-mail: mana.farshid@ltu.se_ E-mail: ess@ltu.se
}

\section{J. Toufighi Zavareh}

Marketing Group, School of Management,

University of Bath,

Bath, BA2 7AY, UK

E-mail: toufighiz@gmail.com

\begin{abstract}
The aim of this research is to investigate customer relationship management (CRM) activities in e-banking among Iranian banks. These banks are already adopting CRM and approaching it differently, and achieving different rates of success in terms of customer satisfaction and CRM. A comparative approach of their attitudes toward CRM, therefore, will reveal important insights. Following similar approaches researchers have employed in Europe, Pakistan, Malaysia, the UK and Ireland, we investigated the touch points and services that connect banks to their customers. According to these researches in other countries, we have developed a theoretical framework to investigate CRM activities in public and private Iranian banks by interviewing with qualitative approach case study. The main components of our research framework are: communicational/collaborative CRM, operational CRM and analytical CRM. We also consider the relationship among the components. This research will reveal Iranian banks' positioning with regard to their view, concept and the benefits of CRM, with a cross-case comparison between Iranian banks' CRM activities and also some conclusions for practitioners.
\end{abstract}

Keywords: customer relationship management; CRM; electronic banking; e-banking; qualitative research.

Reference to this paper should be made as follows: Keramati, A., Farshid, M., Salehi-Sangari, E. and Toufighi Zavareh, J. (2009) 'Customer relationship management activities in e-banking: the case of Iranian banks', Int. J. Electronic Customer Relationship Management, Vol. 3, No. 3, pp.207-235. 
Biographical notes: Abbas Keramati is an Assistant Professor at the University of Tehran, Tehran, Iran. He received his $\mathrm{PhD}$ in the area of IT and productivity. His major teaching and research interests include customer relationship management, information technology management, quantitative analysis for decision making and research methodology.

Mana Farshid is a $\mathrm{PhD}$ student of E-commerce at Lulea University of Technology. She received her MSc in Industrial Marketing and E-commerce from Tarbiat Modares University and Lulea University of Technology. Her major research interest is in e-commerce and customer relationship management.

Esmail Salehi-Sangari is a Professor and the Head of the Department of Industrial Marketing in Lulea University of Technology, Lulea, Sweden. He also heads the Doctoral program in e-commerce at this institution and teaches on its programs around the world, including Ghana, Iran, Spain and Costa Rica. Educated in the USA and Sweden, his research interests are in the areas of B2B e-commerce and his work has been published in journals such as the European Journal of Marketing and Industrial Marketing Management.

Javad Toufighi Zavareh received his Master's degree in Electronic Commerce from Lulea University of Technology, Sweden and his MSc in Marketing at the University of Bath, England. His postgraduate research interests primarily lie in customer relationship management (CRM) and especially CRM in financial services.

\section{Introduction}

Customer relationship management (CRM) is becoming increasingly important in the provision of financial services (Jutla et al., 2001). If a bank develops and sustains a solid relationship with its customers, its competitors will not easily be able to replace it; therefore, this relationship provides for a sustained competitive advantage. Banks can increase their profits by maximising the profitability of the total customer relationship over time, instead of seeking more profit from single transactions. CRM techniques will help banks if they improve the bank's ability to: select, then manage the right client set; determine which products and services should be profitably sold to which client and then help the bank implement this sales plan; reduce the cost of coverage, particularly by improving the productivity of sales professionals while maintaining quality of coverage (Durkin, 2004).

CRM is an attractive area for research because of its relative novelty and exploding growth (Park, 1999). Competition in financial sector is escalating, both from traditional players and new entrants, owing to deregulation. Changing consumer behaviour and needs, globalisation, deregulation, disintermediation and the emergence of new financial service models are all dynamics in the financial services industry (Park, 1999).

The more a marketing paradigm evolves, the more long-term relationship with customers gains its importance (Lindgreen and Antioco, 2005). CRM pursues long-term relationship with profitable customers. It can be a starting point of relationship management to understand and measure the true value of customers since marketing management as a whole is to be deployed toward the targeted customers and profitable 
ones, to foster customers' full profit potential (Rowley, 2002). Corporate success depends on an organisation's ability to build and maintain loyal and valued customer relationships. Therefore, it is essential to build refined strategies for customers based on their value.

Banking has traditionally operated in a relatively stable environment for decades. However, today the industry is facing a dramatically aggressive competition in a new deregulated environment. The net result of the recent competition and legislation is that traditional banks have lost a substantial proportion of their domestic business to essentially non-bank competition. Competition will undoubtedly continue to be a more significant factor while many banks have found themselves in this position with many of their customers (Zineldin, 1996). Unlike manufacturing and some service industries, bankers are not only selling products and services. First and foremost, they are selling their organisation reputation with every 'customer relationship'. A bank has to create customer relationships that deliver value beyond the provided by the core product. This involves added tangible and intangible elements to the core products thus creating and enhancing the 'product surrounding' (Zineldin, 1996).

The focus of CRM helped banks to understand the customers' current needs, what they have done in the past and what they plan to do in the future to meet their own goals (Xu and Walton, 2005; Keramati et al., 2008). The intelligent use of information about customer needs will create long-term, two-way relationship with customers. CRM enables banks to setup such strategies by managing individual customer relationships. From the service oriented industry perspective, customer satisfaction and retention is ensured by solving customer problems quickly. Customer satisfaction is made certain by allocating, scheduling and dispatching the right people, with right parts, at the right time (Xu and Walton, 2005).

In this internet age, when the customer is having access to a variety of products and services it is becoming very difficult for banks to survive. When customer inquiries are not met easily or transactions are complicated, the customer will ask for new levels services and only chose those institutions who are making a real effort to provide a high level of quality, fast and efficient service through all the banks' touch points such as call centres, automatic teller machine (ATMs), voice response systems, internet and branches. This is a difficult situation which CRM is an opportunity that banks can avail to rise above minor advantages by developing actual relationship with their customers. Company committed to CRM must continuously invest in its relationship with its customers, because it is the only competitive advantage remaining to an organisation (Xu and Walton, 2005).

Different CRM activities are already being used in Iranian banks. Some of them are using communicational CRM while others are using operational CRM. Some of these activities are just for view, such as check balances, statements/accounts and historical records. Others are for account controls, which include customer service and support (CSS) activities of operational CRM such as amending accounts, ordering checkbooks, transferring funds, paying bills to third parties, printing statements or standing orders, sending messages and paying credit-card bills.

The aim of this research is to investigate the CRM activities that already exist in e-banking activities in Iranian banks. Iranian banks are already adopted themselves through this mindset. Iranian banks proceed to this important issue differently with various rates of success in customer satisfaction and CRM. Therefore, with a comparative 
approach their attitudes toward CRM will reveal and embrace their success and failure factors. In the similar approaches that researchers have done in the case of Pakistan, UK and Ireland, the touch points and services that connect the banks to their customers were investigated. Considering the above-mentioned description, no prior research has been done in this research area in Iranian context. Based upon this discussion, the problem area has formed as: 'How can CRM activities in Iranian banks be described?'

The other purpose of the research will be some comparative studies between private and public banks in Iran. The study will not only compare public and private banks, it will also investigate their relationships with each other and draw some comparisons within the banks.

The research questions will be formulated according to research problem. Hence, the research questions will be as follows:

- How Iranian banks can manage the analytical CRM? What they will do and what are the strategies?

- How Iranian banks can manage the operational CRM? What they will do and what are the strategies?

- How Iranian banks are managing their communicational CRM? What they will do and what are the strategies?

Due to the structure of this research, first and foremost, literature review will be discussed, then research methodology employed to address the research problem and questions will be discussed. Next a comparison will be presented between the banks in two segments of private and public banks and CRM activities in each bank. Finally, conclusions drawn from the study will be presented and implications for management and suggestions for further research and limitations will be discussed.

\section{Literature review}

\subsection{CRM in banking}

A lot of large banks have been adopting information-driven customer acquisition and CRM, but at this stage, few can show clear bottom-line rewards from this effort (Foss, 2002). However, a number of large banks in the USA, UK, Europe and Australia have invested in data warehouses and data mining tools in the past few years (Ibid.). They have been building models of consumer-segment profitability and behaviour, which help them target direct marketing campaigns for the 'right' groups of customers. They have been analysing and classifying consumer needs, assessing the risk of loss and trying to predict demand and delivery methods for various types of customers. They have been leveraging information for selling and enhancing the effectiveness of new customer marketing campaigns (Foss, 2002).

According to Lindgreen and Antioco (2005), first European bank considered it vital to develop a real-time database as a means to fully understand which types of customers it was dealing with. In fact, customers interact with sales services and customer support services through the distribution network, which comprise every possible channel to contact the bank: agencies, call centres, customer service, home banking, self banking and so on. The bank's interactions with its customers should provide clear information, 
which can then be used by the 'back office' for better marketing and peripheral services (e.g., the presence of a particular employee to serve a particular customer and for cross-selling) (Lindgreen and Antioco, 2005).

There are various definitions of CRM in the literature. According to Chalmeta (2006), CRM is a 'customer-focused business strategy that dynamically integrates sales, marketing and customer care service in order to create and add value for the company and its customers through increased satisfaction and loyalty'.

Tan et al. (2003) suggests that 'the expression 'e-banking services' refers to the set of processes and mechanisms that a virtual agent-based banking institution offers to agents intending to engage in commerce activities in an agent environment'. Continuing technological innovation and competition among existing banking organisations and new entrants have allowed for a much wider array of banking products and services to become accessible and delivered to retail and wholesale customers through an electronic distribution channel collectively referred to as e-banking.

The e-banking services consist of two sub-services: electronic payment service for enabling agents to make and receive payments; and account management service for creating, maintaining and closing bank accounts.

According to Jayawardhena and Foley (2000), customer expectations from electronic banking can be categorised under four different functions, namely, view-only functions to have bank balances in check, action/account control functions to provide customers with the broadest range of access and control over their accounts, applying for new banking services to be able to make applications for core banking services and open new accounts (savings accounts, loans, etc.) and integration reconciliation functions to manage their finances with software packages (Jayawardhena and Foley, 2000).

A well-designed CRM shares the characteristics as:

1 Communicational/collaborative CRM for building online communities, personalising services, developing business-to-business customer exchanges, etc. (Rollins and Halinen, 2005). It makes interactions between a business, its channels and its customers possible. It provides the means for the customer to contact the company and enables collaboration between suppliers, partners and customers.

2 Operational CRM for improving customer service, online marketing, automating sales force, etc. (Rollins and Halinen, 2005). It is the automation of customer-facing processes. It handles the customer contact and processing. It manages and synchronises customer interactions in marketing, sales and service.

The functions include sales force automation (SFA), automatically tracking a client's account history for repeated transactions. The goal of SFA is to allow the sales force to concentrate more on selling and less on administrative tasks (Injazz and Karen, 2003). Enterprise marketing automation (EMA) for evaluating valuable customers and segmentations for some strategic marketing, and CSS for delivering personalised and efficient services to the customers.

3 Analytical CRM for building data warehouses, analysing data, improving relationships, etc. It uses customer data to create a mutually beneficial relationship between a business and its customers (Rollins and Halinen, 2005). This analysis, modelling and evaluation help to optimise information sources for a better 
understanding of customer behaviour, so that make the contact to be more personalised.

These CRM technology applications link front office (e.g., sales, marketing and customer service) and back office (e.g., financial, operations, logistics and human resources) functions with the bank's customer 'touch points' (Fickel, 1999).

As it mentioned before, customer satisfaction is essential for increasing the competitiveness of companies and achieving customer objectives. To improve customer satisfaction, it is necessary to identify customer needs and expectations and ensure they are met. This requires the construction of a measurement system fed by information, part of which will come directly from the customer and part will be extracted from the company's computer system. Data stored in the contact centric database is analysed through a range of analytical tools in order to generate customer profiles, identify behaviour patterns, determine satisfaction level and support customer segmentation. The information and knowledge acquired from the analytical CRM will help develop appropriate marketing and promotion strategies. Therefore, if the bank's systems relating to various types of accounts and services did not recognise that the same customer interacted with bank in a number of ways, relating to different services of the bank, it would not be possible to take a complete view of the customer - and his/her value to the bank. In term $360^{\circ}$ customer view has been coined to refer to this need for a view of the complete set of interactions between an organisation and its customers (Kotorov, 2002; Dyche, 2001).

In summary, analytics drives decision making in operational CRM for the deployment of marketing sales and customer service processes (Reynolds, 2002). But without the data collected via the operational CRM processes, analytical CRM would not have any data to work with. The data processed by analytical CRM tools could not be effectively disbursed and strategic decision making would not occur, without collaborative CRM. Collectively, operational CRM, analytical CRM and business intelligence work simultaneously to drive the customer life cycle (Reynolds, 2002).

Reynolds (2002) suggests that CRM applications can commonly comprise: call centre automation, campaign management, contact management, data warehousing, e-mail management, field service automation, knowledge management (KM), marketing automation, personalisation and SFA. Rapidly improving technology has allowed organisations to make the best of each customer contact. Each relationship exchange incurs transactional and/or non-transactional data. Transactional data typically include sales amount, transaction time, place and buyers while non-transactional data may include inquiries or feedback in the form of complaints or suggestions. Both transactional and non-transactional data must be organised into an integrated customer data profile because such information is what makes customer interaction powerful (Wells et al., 1999).

Enabled by advanced information technologies, banks can now collect unprecedented amount and depth of data on their customers and turn them into information for their strategic business purposes. Here, the important issues are: to identify what kind of information they need; about whom they will collect this information; and how they will manage such information for future use. Once able to identify its customers, a firm can make its customer-base more loyal by collecting, processing and applying customer profile and transaction data to create in-depth understanding of customer needs and provide fair value to all customers. According to the content and interaction types, 
customer information can be classified into three types: information of-the-customer which personal and transaction data about a customer; information for-the-customer is the product, service and organisational information that is perceived useful by customers; and the third type is 'by-the-customer' information. This is the non-transactional customer feedback information that includes customer complaints, propositions, claims, etc. (Wells et al., 1999).

Segmentation is a key method employed by banks to better understand and service their customers in this increasingly competitive environment. The goal is to solve the conflict between the intentions to satisfy customer needs as individually as possible but also to allocate marketing resources as economically as possible (Machauer and Morgner, 2001).

\subsection{Research framework}

The purpose of this section is to build an appropriate frame of reference for investigating CRM activities in e-banking of Iranian banks.

By customer management, banks are going to find the right customers (those with an acceptable current and future net value), getting to know them (as individuals or groups), growing their value (if appropriate) and retaining their business in the most efficient and effective way.

Figure 1 The emerged framework investigation of CRM activities in Iranian banking industry

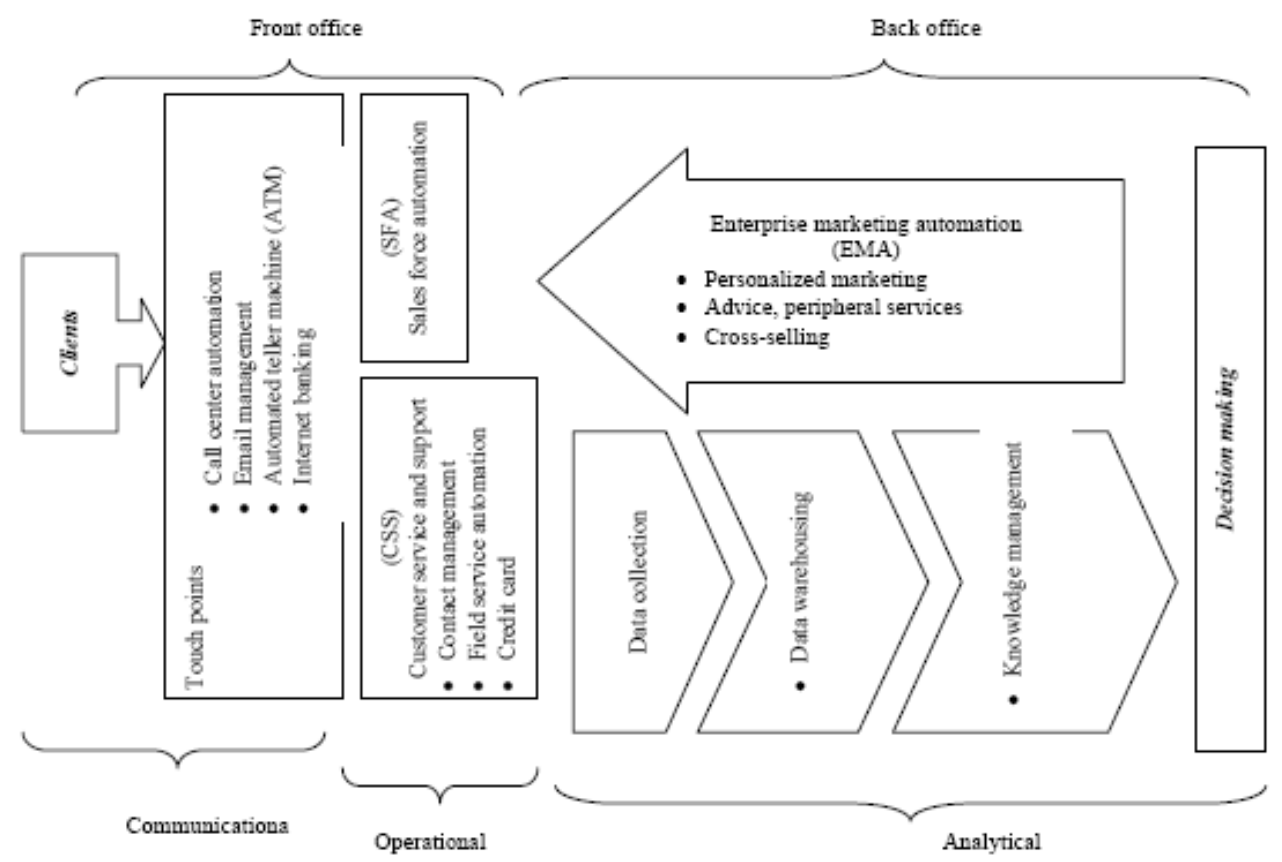

Hence, banks can improve customer retention and loyalty; customers stay longer, buy more often and increased long-term value; higher customer profitability because of lower costs of recruiting customers and no need to recruit so many customers to maintain a 
steady volume of business; reduced cost of sales, as existing customer are usually more responsive (Stone et al., 2002).

An essential part of the information is gathered from the customers through different channels. It is important for these channels to be integrated and gathered in a single database. The analytical part of the CRM should be able to create a variety of customer segments considering customer feedbacks from the database. These segments will be used to design decision making algorithms by the operational part and then will be presented to the customers. Unless the above-mentioned steps are conducted one after another in a chain format, the process will not be performed successfully.

As a result of the literature review, Figure 1 is presented which shows the emerged investigation of CRM activities in banking industry. The introduced framework in Figure 1 would be the basis of the current investigation on banking activities of four public and private Iranian banks.

\section{Research methodology}

Figure 2 shows methodology of this research schematically. As Figure 2 shows research approach and strategy are determined based on research problem. Research approach and strategy are described in this section as well as methods of data gathering, data analysis and quality issues.

Figure 2 Research methodology

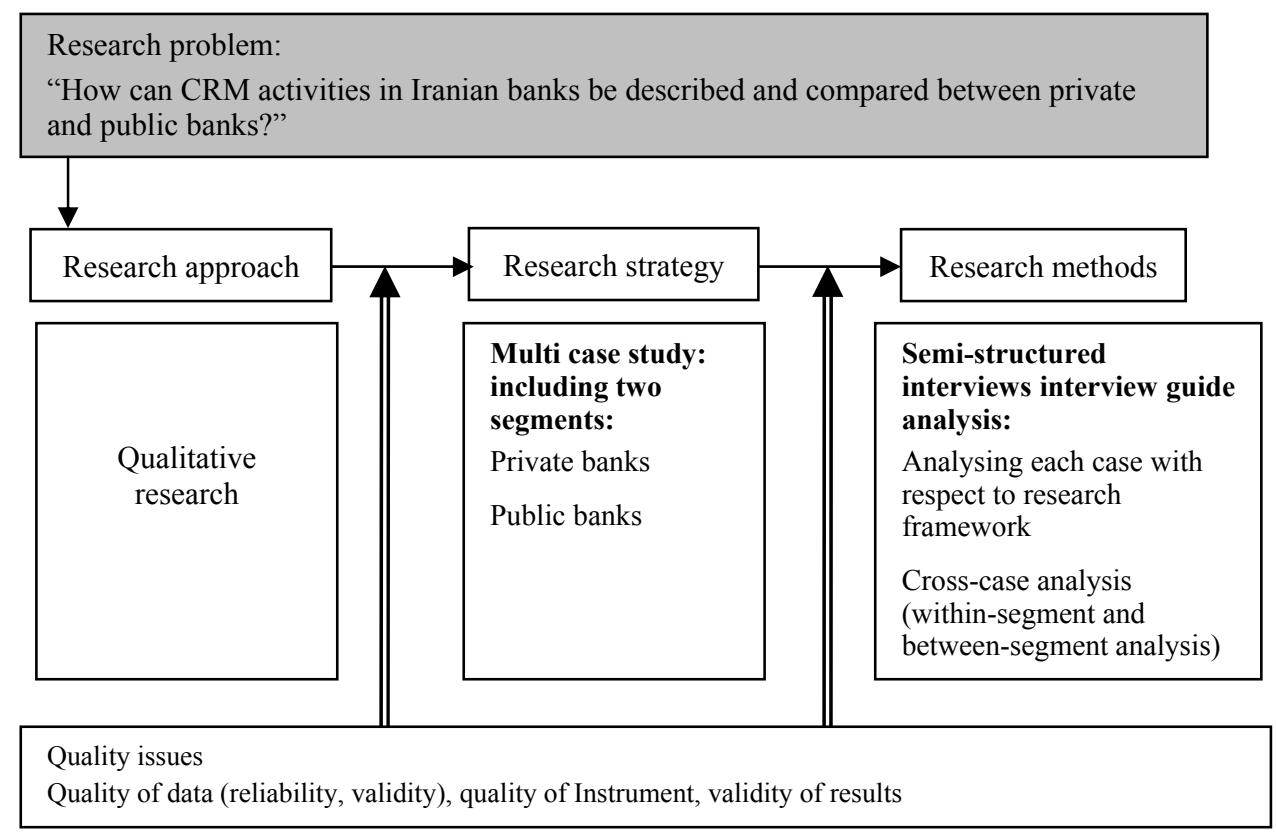




\section{Research approach and strategy}

As the purpose of this study is to gain an in-depth understanding of the CRM activities in e-banking of Iranian banks, the selection of qualitative approach was found to be more appropriate to fulfil the stated purpose since case studies are being used and it requires assessing abundant information. In addition, as this study is intended to explore, describe and find as many as detailed and complete information as much as possible, the qualitative approach is found the most appropriate method of study. In this research, multiple-case study design was selected due to the fact that this research is not dependent on a single, critical, extreme, unique or revelatory case. Furthermore, multiple-case studies will provide more in-depth information about the research problem concerning definitions, profits and different characteristics of CRM in e-banking, thus will result in a higher degree of validity (Zineldin, 1996).

\section{Data gathering technique}

The data for this study that is collected is expected to be mainly of a qualitative nature since it is in the form of words and not derived from numbers. The data gathering technique is semi structure interview.

\section{Instrument}

The instrument is interview guide which is conducted based on frame of reference of the literature review and also some information and knowledge from pilot survey. The interviews are conducted in semi-structured form.

\section{Quality of instrument}

In the spite of preparing the interview guide with open ended questions, was pre-tested by a number of researchers from CRM, management and banking fields and also by industry representatives. Additionally, the instrument was also reviewed by a number of researchers, thus, higher level of validity and reliability could be achieved. Suggestions from this group resulted in an additional modification of the interview guide.

To increase the validity and reliability of the research instrument, used to collect data, the interview guide was evaluated by attendees from banks participating in the pilot study so that it can provide a comprehensive view, the interviewees were contacted in advance about the matters were going to be discussed and also to assure that they are qualified for our interviews. Some suggestions resulted in modification of the interview guide.

\section{Unit of analysis}

Considering the fact that the research problem deals with competencies between Iranian banks, CRM is an opportunity that banks can avail to rise above minor advantages by developing actual relationship with their customers, the unit of analysis is the whole bank (marketing, CRM, public affair, credit and facilities, decision making and also IT departments). 


\section{Data analysis method}

The data of this research are gathered from four Iranian banks, two of them are public and two are private. All the banks involved are commercial and target the same audience. They all serve the public. This study deals with a complex phenomenon of context and a variety of cases studied (private and public banks) within a pre-defined conceptual framework (presented in Figure 1). Thus, an analytical strategy that relies on the theoretical framework developed has been used. In order to compare the two categories (public and private banks), a four-fold matrix is designed enabling us to compare and analyse. In order to extract the suitable data, a search was done inside the organisation to find the expert personnel who are somehow involved in the CRM process. Field notes and documentation have been translated from Persian to English because all the interviews were conducted in Persian, rewritten, revised, coded and displayed in accordance with the conceptual framework.

As Figure 3 shows, three steps were followed for data analysis of this research. First, the data is reduced through a case analysis where the four cases compared with the theory in the frame of reference. Second, all of the data will be reduced further through being displayed in order to have a cross-case comparison between cases in each section, which means private and public banks and then in the third step it will have cross-case analysis between each section, comparison between private and public banks based on the research questions. Finally, conclusions will be drawn based on the each case and cross-case analysis.

In order to do cross-case analysis of the data, similarities and differences across the cases were located and analysed. It is important to say that, the interview protocol included questions standardised around topics such as a manager's perception of what CRM constitutes, the objectives and the benefits of the CRM programmed on the technological and organisational infrastructure of the bank.

\section{Quality of data}

Yin (2003) states that the process of data gathering is complex in case studies and the case study researchers, therefore, must have 'a methodological versatility' and need to 'follow certain formal procedures to ensure quality control during the data collection process'. The main method of data collection selected for this study was personal interviews, as this method is insightful (Yin, 2003) and makes it possible to gather large amounts of data quickly, with a potential for immediate follow ups and clarifications (Marshall and Rossman, 1999). In addition to personal interviews, documentation, mainly containing bank information (annual reports, organisational charts, brochures, web pages) has been used as a means to confirm and strengthen evidence from other sources. The focused interview allows an informal conversation, though it is partly structured: 'following a certain set of questions derived from the case study protocol'. Finally, the structured interview is guided by a thorough set of pre-designed questions and, thus, resembles a formal survey.

Furthermore, Yin (2003) states that reliability aims at minimising errors and biases in a study. In this study, attempts to reduce the biases have been made by carefully describing the data collection method and through extensive and thorough documentation of each bank. In order to increase the reliability of this research, the researchers will try to avoid leading, subjective questions and will take notes during the interviews. 
Furthermore, the interviews were recorded by a voice recorder. The data validity was ensured through multiple sources of evidence (multiple interviewees and document analyses) and by the interviewees reviewing the case interpretations.

\section{Validity of results}

The final emerged theory would be once again validated by interviewing a sufficient number of experts in each case, using the feedback method which means that after analysing the data which were gathered the results were shared with experts in each bank and checked them all. In this way, the participants were given an opportunity to corroborate or disagree with the main findings of the study.

\section{Findings}

Miles and Huberman (1994) further point out that there are two types of data analysis: within-case analysis and cross-case analysis. The within-case analysis is carried out when collected data in a single case will be compared with the theory included in the frame of reference to identify the differences and similarities. In the cross-case analysis, where several cases are involved, the objective is not only to compare those cases with each other but also to be able to increase generalisability.

Figure 3 Three steps of data analysis: case analysis (Step 1); cross-case analysis: within segment comparison (Step 2); and between segment comparison (Step 3)

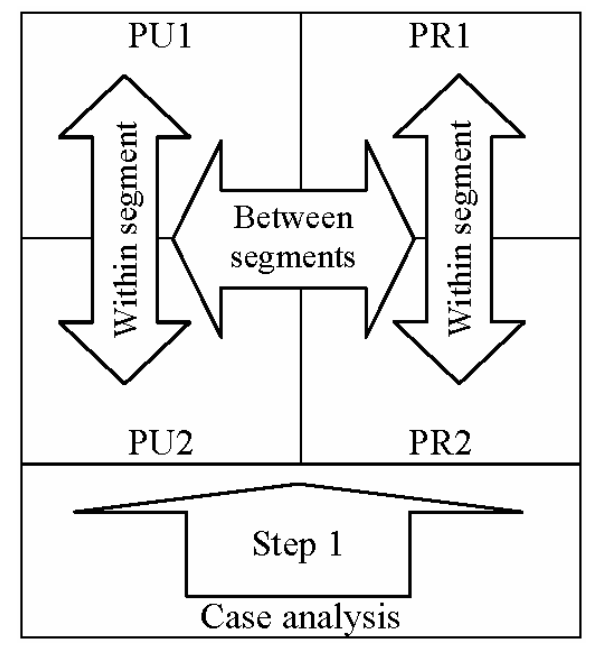

In this section, the empirical data collected from documents and interviews of four selected banks which are named PR1, PR2, PU1 and PU2 banks. They are separated into two groups based on the public (PU) and private (PR) sections. The data is collected and analysed based on our frame of reference (Figure 1) and the interview guides (Appendix) which are going to describe above. The data has been analysed in two levels of analysis. At the first level, results obtained from each case is reported separately and analysed based on theoretical framework presented in Figure 1. At the second level of analysis, a 
cross-case approach for data analysis is applied. Figure 3 summarises cross-case analysis method which includes within segment and between segments analysis. Within segment analysis is devoted to comparing private and public banks (PR1 vs. PR2 and PU1 vs. PU2) and between segment analysis includes comparison between public banks and private banks (PR vs. PU).

\subsection{Case analysis}

\section{PR1}

In this section, the data were reduced through a case analysis where each case compared with the theory in the frame of reference (Figure 1).

Table 1 Communicational CRM (touch points) in private and public banks

\begin{tabular}{|c|c|c|c|c|}
\hline $\begin{array}{l}\text { Communicational } \\
\text { CRM }\end{array}$ & PRI & $P R 2$ & PU1 & PU2 \\
\hline $\begin{array}{l}\text { Automated teller } \\
\text { machine }\end{array}$ & $\checkmark$ & $\checkmark$ & $\checkmark$ & $\checkmark$ \\
\hline Branch & $\begin{array}{c}\checkmark \text { One-to-one } \\
\text { experience }\end{array}$ & $\begin{array}{c}\checkmark \text { Customer } \\
\text { feedback }\end{array}$ & $\begin{array}{l}\checkmark \text { Customer } \\
\text { identification, } \\
\text { service quality } \\
\text { for staff }\end{array}$ & $\checkmark$ Customer data \\
\hline Call centre & $\begin{array}{l}\checkmark \text { CRM } \\
\text { communication, } \\
\text { financial advice }\end{array}$ & & $\checkmark$ Feedback & $\begin{array}{c}\checkmark(1,556 / \text { smart } \\
\text { customer } \\
\text { communication }) \\
\text { - feedback } \\
\text { information }\end{array}$ \\
\hline $\begin{array}{l}\text { E-mail } \\
\text { management }\end{array}$ & & $\begin{array}{l}\checkmark \text { Information } \\
\text { and tracking) }\end{array}$ & & $\checkmark$ \\
\hline Help desk & & $\checkmark$ (in progress) & & \\
\hline Internet banking & $\checkmark$ (e-payment) & $\checkmark$ & $\checkmark$ & $\begin{array}{c}\checkmark \text { (check balance, } \\
\text { transferring funds, } \\
\text { paying bills, } \\
\text { customer contact) }\end{array}$ \\
\hline Mobile banking & $\checkmark$ (pilot) & & $\begin{array}{l}\checkmark \text { (offline/just } \\
\text { for view) }\end{array}$ & $\checkmark$ \\
\hline Pin pad & & $\checkmark$ & & \\
\hline POS & $\checkmark$ & $\checkmark$ & $\checkmark$ (online) & $\checkmark$ \\
\hline \multicolumn{5}{|l|}{$\begin{array}{l}\text { Special customer } \\
\text { portals }\end{array}$} \\
\hline $\begin{array}{l}\text { Telephone } \\
\text { banking }\end{array}$ & $\checkmark$ & $\checkmark$ & $\begin{array}{l}\checkmark \text { (offline/just } \\
\text { for view) }\end{array}$ & $\checkmark$ \\
\hline
\end{tabular}

Broadly speaking, PR1 Bank provides its services in two ways for serving the customers:

1 Via branches and traditional banking system: Increasing the number of branches from 24 to 156 during two years with the purpose of extending services. 
2 Via expanding e-banking: Considering the priority of electronic banking, during the last two years PR1 Bank provides several services employing various mechanisms with the purpose of providing customers at their home or work. This approach includes marketing activities in following areas: electronic card services: perusing public and private organisations to use such cards for paying salaries or bounces, extending the use of ATMs and point of sale (POSs), expanding the internet payment method identifying and contracting one-by-one with the websites offering e-selling services [smoothing the e-payment processes, telephone banking, short message service (SMS) banking and ATMs for its customers by the permission of the responsible ministry and contracting with telephone, electricity and other supplier companies] and also telephone bank, SMS bank and internet bank (Table 1).

About PR1 Bank, in order to make good decisions and strategies, it requires controlling its relationship with its customers in order to mitigate and manage the risks. Currently, integrated CRM, management information system (MIS) and risk management systems are being implemented.

PR1 Bank started its career with a limited and special set of customers requiring few branches and no need for CRM system. But when the so-called paradigm shift occurred, it required attracting customers and offering competitive benefits. Actually marketing and CRM office slowly formed. Then PR1 defined subsets; hence, valuing the customers who are appropriately served which leads them to regular contact with the bank, offering them all they need. PR1 tried to establish a creative relation with customers leading to added value for them. Moreover, PR1 realised that all valuable data can be extracted from CRM so they could create reports regularly.

PR1 considers CRM as a benefit to control their subsidiary companies and supply their information by measuring their performance. At the beginning this was very premature but slowly this new CRM was established with some cultural efforts. E-banking services were setup because they wanted to be in regular contact with its customers. Another approach is to increase the branches along with ATM and POS services which demand CRM systems.

The private banks in this study are members of Tehran Stock Exchange. Their big customers have considerable turnovers and bank activities which influence the EPS and stocks' price. Hence, it is apparent that PR1 needs to be well involved with their customers. In the case of analytical CRM, as shown in Tables 3(a) and 3(b), PR1 Bank, collects data via its website, call centre and branches which further provides information resulted in customer satisfaction and core banking data, then combining them with the events occurring in the society makes decisions in line with system integration, product innovation and redundant competency. Customer profile generation is not done uniformly yet here, nor is customer behavioural patterns detected. Marketing application development promotion is not done clearly from the knowledge.

In the case of operational CRM, PR1 Bank has managed to serve its customer and trace their requests using call centre (Table 2). Valuable customers are detected by the traditional way in the branches or following a request from the database. In order to communicate with its customers, PR1 has increased the number of branches and the serving hours. In the branches PR1 establishes special relationship with its customers in a traditional way. In the call centre, PR1 serving customers 24 hours a day/seven days a week/365 days of year. 
Table 2 Operational CRM activities in private and public banks

\begin{tabular}{|c|c|c|c|c|c|}
\hline \multicolumn{2}{|c|}{$\begin{array}{l}\text { Operational CRM } \\
\text { activities }\end{array}$} & \multirow[t]{2}{*}{$P R 1$} & \multirow[t]{2}{*}{$P R 2$} & \multirow[t]{2}{*}{ PU1 } & \multirow[t]{2}{*}{ PU2 } \\
\hline \multirow{10}{*}{ 气े } & $\begin{array}{l}\text { ATM monitoring } \\
\text { with remote access }\end{array}$ & & & & \\
\hline & $\begin{array}{l}\text { Branch } \\
\text { (traditionally) }\end{array}$ & & & & $\checkmark$ \\
\hline & Call centre & $\checkmark$ & & $\checkmark$ & \\
\hline & $\begin{array}{l}\text { Contact } \\
\text { management } \\
\text { (smart customer } \\
\text { communication) }\end{array}$ & & & & $\checkmark$ \\
\hline & Credit card & $\checkmark$ (pilot) & $\checkmark$ & & \\
\hline & Electronic cards & $\checkmark$ & & & \\
\hline & $\begin{array}{l}\text { Field service } \\
\text { automation }\end{array}$ & & $\begin{array}{l}\checkmark \text { (information } \\
\text { for tracking the } \\
\text { process in } \\
\text { foreign exchange } \\
\text { department) }\end{array}$ & & $\begin{array}{l}\checkmark \text { (special } \\
\text { customer } \\
\text { portals) } \\
\text { (in progress) }\end{array}$ \\
\hline & Help desk & & $\checkmark$ & & \\
\hline & $\begin{array}{l}\text { International } \\
\text { service }\end{array}$ & & $\checkmark($ cards $)$ & & \\
\hline & $\begin{array}{l}\text { Queue system } \\
\text { from branches }\end{array}$ & & $\checkmark$ & & \\
\hline \multirow{2}{*}{$\underset{\mathbb{1}}{\mathbb{Z}}$} & $\begin{array}{l}\text { Mass marketing, } \\
\text { advertising, } \\
\text { marketing }\end{array}$ & $\checkmark$ (SMS, ads.) & $\checkmark$ Traditionally & $\begin{array}{l}\checkmark \text { Public } \\
\text { affair }\end{array}$ & \\
\hline & $\begin{array}{l}\text { Personalised } \\
\text { marketing }\end{array}$ & $\begin{array}{c}\checkmark \text { (loyalty system } \\
\text { with credit cards) } \\
\text { (pilot) }\end{array}$ & $\begin{array}{l}\checkmark \text { (by human } \\
\text { connections) }\end{array}$ & & $\begin{array}{l}\checkmark \text { (special } \\
\text { package } \\
\text { customers) }\end{array}$ \\
\hline$\frac{\pi}{5}$ & $\begin{array}{l}\text { Online } \\
\text { documentation } \\
\text { (special } \\
\text { customers/facilities } \\
\text { office) }\end{array}$ & & & & $\checkmark$ \\
\hline
\end{tabular}

\section{PU1}

In the case of PU1 Bank, there is no such system as CRM. There are divisions which are doing this in the traditional way. Public Affairs Department does the customer support and advertising like informing people what services are offered. They have built a call centre which is going to become a contact centre. Except for phone, other services like SMS or internet are pretty new here. They are responsive but the backing tree of knowledge is flawed. There is no CRM system for the customer. There is an activity cycle with some parts manual, some parts are batched and some parts are automated or online. PU1 Bank is now maintaining 2,010 branches throughout the country. PU1 Bank's ultimate goal is to meet their shareholders expectations. Considering their only shareholder is the state, PU1 should do as to satisfy the state's expectations. 
Complementary services like cards or ATM is important in this bank because it attracts customers (Table 1). Otherwise it has lost the competition to other banks. Customers are now well aware of what they want and who can give it to them. Hence, due to the fact PU1 has to serve their customers first and also make mutual relationship with them. In order to compete in the field, PU1 believes that it should identify the customers in branches and has access to their history and transactions; thus, PU1 is after informing and integrating data which is only possible via the suitable infrastructure. Regarding other touch points like internet, they have to pursue managers to adopt these new services.

Table 3a Analytical CRM activities: data collection and data warehousing

\begin{tabular}{|c|c|c|c|c|c|}
\hline \multicolumn{2}{|c|}{$\begin{array}{l}\text { Analytical CRM } \\
\text { activities }\end{array}$} & PR1 & $P R 2$ & PU1 & PU2 \\
\hline \multirow{10}{*}{ 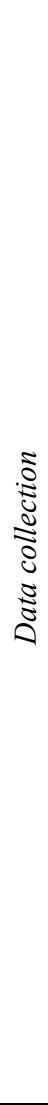 } & $\begin{array}{l}\text { ATM } \\
\text { monitoring with } \\
\text { remote access }\end{array}$ & & $\checkmark$ & & \\
\hline & Branch & $\begin{array}{l}\checkmark \text { Customer } \\
\text { satisfaction, } \\
\text { core banking } \\
\text { (Negin) }\end{array}$ & $\begin{array}{l}\checkmark \text { (customer } \\
\text { feedback, } \\
\text { behaviour) }\end{array}$ & $\checkmark$ (feedback) & $\begin{array}{c}\checkmark \text { (customer } \\
\text { satisfaction, } \\
\text { customer loyalty } \\
\text { behaviour) }\end{array}$ \\
\hline & Call centre & $\checkmark$ & & & $\begin{array}{l}\checkmark \text { (feedback of } \\
\text { ads., queue } \\
\text { technique, } \\
\text { timing) }\end{array}$ \\
\hline & $\begin{array}{l}\text { Core banking } \\
\text { (SGB) }\end{array}$ & & & $\checkmark$ & \\
\hline & Exit interview & & & $\checkmark$ & \\
\hline & Focus group & & & $\checkmark$ & \\
\hline & $\begin{array}{l}\text { Queue system } \\
\text { from branches }\end{array}$ & & $\checkmark$ & & \\
\hline & $\begin{array}{l}\text { Secondary data } \\
\text { of socially }\end{array}$ & & & $\checkmark$ & \\
\hline & $\begin{array}{l}\text { SHETAB } \\
\text { (ATM } \\
\text { operations in } \\
\text { contrast of } \\
\text { competitors) }\end{array}$ & & & $\checkmark$ & \\
\hline & Website & $\checkmark$ & & & $\begin{array}{c}\checkmark \text { (tracing } \\
\text { customer } \\
\text { navigation and } \\
\text { such) }\end{array}$ \\
\hline 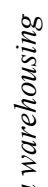 & Databases & $\begin{array}{c}\checkmark \text { (not } \\
\text { integrated) }\end{array}$ & $\begin{array}{c}\checkmark \text { Separate } \\
\text { databases }\end{array}$ & $\begin{array}{l}\checkmark \text { (offline) } \\
\text { (Roaming } \\
\text { accounts } \\
\text { database) } \\
\text { (online) }\end{array}$ & $\begin{array}{c}\checkmark \text { Different } \\
\text { huge databases }\end{array}$ \\
\hline$\frac{a}{\tilde{z}}$ & $\begin{array}{l}\text { Data } \\
\text { warehousing }\end{array}$ & & & & $\checkmark$ (in progress) \\
\hline
\end{tabular}


As illustrated in Tables 3(a) and 3(b), in analytical CRM, data analysed by the decision making unit but information like customer feedbacks from the branches or contact centre are not used in the way of strategy planning. Due to some infrastructural issues, data are not available in real-time and online. Database is designed in a way capable of providing some specific statistics and data but it is not possible to identify a unique customer in different branches. Results of focus groups and exit interviews are used to take better strategies. Risk management is precisely done here using the gathered data from the database. As the bank managers mentioned in the interviews, this bank buys some secondary data of society from data seller companies. They actually use this for market analysing which is done traditionally but by managers who are very experienced. This bank controls their competitor's card transactions in their ATMs in order to compare it with their own and planning strategies in this part.

Due to the lack of information about customer's behaviours and subsequently lack of segmentation, it is not possible to decide for advertising purposes and other services. As regards with communicational CRM (Table 1), PU1 hold focus groups in which managers directly get feedback from customers, gathering their suggestions and views. PU1 believes that this improves their relation with customers and makes them feel a sense of loyalty and closeness to the bank.

\section{PR2}

PR2 Bank started its business in 2002 upon concurrent inauguration of four branches. The special object is to improve economical affairs by developing industrial activities by supplying facilities and expanding new finance tools and also financially supporting construction, trading and consumption industries. CRM is done inside the banking system without any specialised sub system.

IT manager said that:

"CRM is possible when accompanied by strategic management and planning. If the customer knows that the system is operating according to the current needs, he will keep his connection with the bank continuously (mutual relationship). The only way to see and keep the customer's needs close is to store them uniformly in a database."

Some strategies like CRM see major modifications when high-ranking managers change. Some are under the influence of environmental and social effects. These should be adaptable and updated accordingly. PR2 Bank tries to discover customer's demands by studying their way of living and priorities in their requests and then they design new services and tools [Tables 3(a) and 3(b)]. This is yet immature and is not performed amply. PR2 believes that environmental and economical fluctuations have a huge impact on the bank. CRM vision in PR2 bank is to manage service cycle by focusing on beneficent customers directing them towards up-selling and cross-selling. Keeping the customer is vital for them and they perform all these various customer-related programs in order to raise the profit and decrease the costs. They try to offer high quality services, thus keeping the customer permanent and satisfied leading to more income. In order to be capable of serving CRM demands, data uniformity and integrity are necessary all over the bank. Data mining is done in planning and development unit for plan to identify branches to install TV sets, banners and a trained employee explaining services to customers in a cosy environment [Tables 3(a) and 3(b)]. 
Table 3b Analytical CRM activities: KM and decision making

\begin{tabular}{|c|c|c|c|c|c|}
\hline \multicolumn{2}{|c|}{ Analytical CRM activities } & PR1 & $P R 2$ & PU1 & PU2 \\
\hline \multirow{16}{*}{ 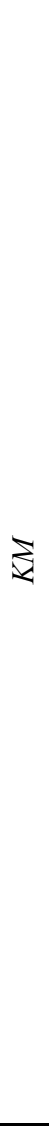 } & $\begin{array}{l}\text { Customer } \\
\text { segmentation }\end{array}$ & $\checkmark$ & $\begin{array}{c}\checkmark \text { (not integrated, } \\
\text { different in } \\
\text { departments) }\end{array}$ & $\checkmark$ (traditionally) & $\checkmark$ \\
\hline & $\begin{array}{l}\text { Customers } \\
\text { behaviour }\end{array}$ & & $\checkmark$ & & \\
\hline & Customers churn & & & & $\checkmark$ \\
\hline & $\begin{array}{l}\text { Data analysis (CLV, } \\
\text { customer churn) }\end{array}$ & & $\checkmark$ & & \\
\hline & $\begin{array}{l}\text { Economical } \\
\text { information }\end{array}$ & & $\checkmark$ & & \\
\hline & $\begin{array}{l}\text { Environment } \\
\text { information }\end{array}$ & $\checkmark$ (competitors) & & $\checkmark$ & \\
\hline & Financial issues & $\checkmark$ & & & \\
\hline & Focus group & & & $\checkmark$ & \\
\hline & $\begin{array}{l}\text { Manually data } \\
\text { mining }\end{array}$ & & & & $\checkmark$ \\
\hline & Market analysis & & & $\checkmark$ & \\
\hline & Product innovation & $\checkmark$ & & & \\
\hline & $\begin{array}{l}\text { Public affairs } \\
\text { (feedback) }\end{array}$ & & & & $\checkmark$ \\
\hline & $\begin{array}{l}\text { Redundant } \\
\text { competency }\end{array}$ & $\checkmark$ & & & \\
\hline & Risk management & & $\checkmark$ & $\checkmark$ & \\
\hline & $\begin{array}{l}\text { Secondary data of } \\
\text { society }\end{array}$ & & & $\checkmark$ & \\
\hline & System integration & $\checkmark$ & & & \\
\hline \multirow{6}{*}{ 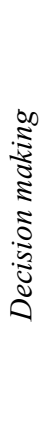 } & $\begin{array}{l}\text { Balance score card } \\
\text { (BSC) (in progress) }\end{array}$ & & & & $\checkmark$ \\
\hline & Decision making & & $\checkmark$ & $\checkmark$ & \\
\hline & $\begin{array}{l}\text { Master plan } \\
\text { (in progress) }\end{array}$ & & & & $\checkmark$ \\
\hline & MIS & $\checkmark$ (in progress) & & & $\checkmark$ \\
\hline & Risk management & $\checkmark$ (in progress) & & & \\
\hline & $\begin{array}{l}\text { Web-based } \\
\text { management } \\
\text { application }\end{array}$ & & & & $\checkmark$ \\
\hline
\end{tabular}

As shown in Table 2, in the operational CRM section, PR2 bank has initiated a call centre performing some help desk activities without any data output and analysis. Regarding SFA which is all about ability to tracking the customer's account, a suitable service is available for foreign exchange department. This service is being promoted and upgraded. Personalised marketing is done by the human connections. Bank has performed many activities regarding e-banking and various services which is one of the improvements of the country's banking system. But information acquired from these touch points are not 
gathered and analysed properly; hence, no feedback exists for advertising planning and marketing.

\section{PU2}

About PU2 Bank, they tended to have infrastructure for implementing the workflow management to integrate the different CRM activities through the banking network such as special services of tele-banking, SMS and internet banking and various cards such as electronic wallet (Table 1).

In the past, heads of the branches used to know their customers in their minds but as customers increased, this approach proves useless. Therefore, they had to segment them and finally automate this process and add some mechanisms to it. Hence, they find themselves in the need of controlling and managing their relationship with their customers through their branches and other touch points. There are different sections which are not integrated yet. They are in the contact management phase at the moment and have not step into analysis yet. At the back of the CRM is the core banking project which is going to provide a complete information flow of the banking data. Upon request data are fetched from database, but back office should have the request of the front office to provide such information. Complaints are gathered from the system and then being taken care of at the supervision division. This would be the most important benefit of managing customer relationship from their viewpoint.

None of the bankers currently offer any special kind of services to their special and core customers. They basically do what others do more quickly or with extra features to some owners of the current accounts that they refer to them as special customers. Bank's viewpoint is that customer is customer, yet some special customers may have the same services in other ways. These services may vary according to branch managers' knowledge about the customer.

In case of customer relation, focus should be shifted towards the contact centre (Table 1). This centre should be capable of handling all the communications and gates to the customers like fax, e-mail, telephone and other channels. It should have a smart tracing system. Queue technique, timing for the operators, managing internal group and reporting are some of the other highlights. Customer information is registered in the system as transactions. Each part of customer information is gathered in new services. Researches then use this data. There is no such a system to take customers data as input and then performs analysis and segmentation on them in order to do marketing or attract new customers. Older systems do the statistics manually and somehow data mining. New systems ask for customer's national code and a few more items but these are not entered into customer's account, even if they do, there is no centralisation and uniformity.

In the operational CRM section, (Table 2), a websites is designed to serve valuable customers. In the primary steps, SFA is done which leads to saving time and energy of both customer and bank. The goal is to serve the customers better. Hence, the output of systems is analysed. Electronic banking is done very well here comparing to either public or private banks but it is not known due to the lack of adequate publicity.

Different approaches and various ways are used to communicate with the customers but due to being big organisation and relatively large number of branches, branches require a long time in order to collect customer information in a data-warehouse. From their point of view, first special customer services should be initiated and then steps should be taken towards integration [Tables 3(a) and 3(b)]. 


\subsection{Cross-case comparison analysis}

In this section, all of the data will be reduced further through being displayed in order to have a cross-case comparison between cases. Finally, conclusions will be drawn based on the each case and cross-case analysis.

\section{Private banks}

Comparison of PR1 and PR2 Bank will be discussed in this section. CRM is done inside the banking system without any specialised subsystem. The only reason to have CRM is the competition to keep the customer satisfied and absorb new customers because it is the customer who keeps the bank running. High competition exists among the banks and particularly among the banks in the private sector. Growing branches, lack of qualified personnel, the necessity for providing precise and whole services demands CRM systems. In private sector, it is necessity to attract the customers due to not having any support or sponsor such as public banks to count on. The private banks believe in offering high quality, new e-banking services and since they are in the embryonic stage of their experience, thus focusing on expansion and they think at the next stage they are going to improve the quality of their services. As it mentioned before, PR1 Bank have done some communicational CRM through the call centre which makes is more powerful in collecting information and managing customer relationship. Both of them are trying to cover the different e-banking services and support their systems with various facilities and have competition with each other on this case. Both private banks work with queue system from branches but PR2 Bank has much more control on the information gathered from this service for proving the quality of its services in branches and does some analysis through serving customers. Furthermore, they have some problems with their core banking systems which is very important for having the customer's transactional information for different purposes such as segmentation, customer life time value, customer churn, etc.

\section{Public Iranian banks}

In spite of trend discussed, PU1 Bank and PU2 Bank compared as two cases were known as Iranian public banks. Iranian public banks' ultimate goal is to meet their shareholders expectations. Considering that their only shareholder is the state (government), and the state wants them to receive people payments for public services, although it incurs loss they should do as to satisfy state's expectations. As mentioned before, public banks are supposed to create job opportunities, invest in new services, providing public companies with facilities is regarded as the last in benefit making. And customer satisfaction, in case of absorbing their mandatory supplements especially personal customers is not the priority goals of public banks. Government wants them to serve the public customers and do their job well. In the Iranian public banks' point of view, customer is customer; yet some special customers may have the same services in more delicate ways. These services may vary according to the managers' knowledge about the customer. Customer tracking is generally difficult and especially in the public banks it is even more difficult due to the lack of a centralised banking system. A customer may have a short-term account in a branch and it is not easy to track. Both public banks extract customer's information (like his history or if he has been a good pay or not) in order to respond to 
them. They are after customer's behavioural patterns and their loyalties. The growth trend of PU1 Bank, in contrast with PU2 Bank, goes somehow at the slower pace in case of electronic-based services and infrastructures because of their experience in the traditional CRM through the years of serving the customers, they have such valuable processes and knowledge but they don't have the facilities to improve the waste operations through the market.

\section{Public and private Iranian banks}

As it is shown in Figure 3 it will have an analysis between each segment, which means comparison between private and public banks based on the research questions. Finally, conclusions will be drawn based on each case and cross-case analysis. Therefore, the next step of the research will be some comparative studies between two major types of banks which are private and public in Iran. Visions are different in public and private banking. Private banks started their way by centralised banking systems; they have fewer branches and thus fewer customers. They could not be compared to public banks. Public banks are bigger, larger and older and it takes a long time to uniform their system. Upon request, data are fetched from database but back office should have the request of the front office to provide such information. Complaints are gathered from the system and then being taken cared of at the supervision division. Private banks are starting their work based on e-banking and working on that to better serve and supply customer needs but public banks are trying to convert their bases and formats from traditional banking to the next generation of banking; hence, they will have different kinds of problem in this way and it will take much more time, energy and money. In public banking, these banks have few big customers; most of them are also in public sector; therefore, it is not up to them to work with some bank of their own choice. This means public banks have no special mechanism neither to attract nor absorb them. Increase in the income and decrease in the costs are among the specific goals. Big customers are not very highlighted though. They said that they serve all the customers; although they pay a little more attention to big ones.

\section{Theoretical and managerial implications}

On the theoretical part, an emerged framework comprise investigation of CRM activities in Iranian banking industry is proposed which can be further investigated in other contexts and see if it can be confirmed in those countries. On the practical part, how to implement the analytical, communicational and operational CRM systems for CRM activities is beyond the scope of this paper, however, some issues tend to be critical to all types of CRM systems' success; thus are outlined below and should be taken into account when implementing CRM systems. In spite of the data which were gathered and analysed based on frame of reference Figure 1 and Tables 1, 2 and 3 which were presented before, some managerial implications regarding using CRM strategy in Iranian banks will be described as follows. 
1 Continual training regarding CRM considering process, responsibilities and technologies: High ranking managers should be trained in order to stimulate their sense of responsibility; training specialists not to have a technological view of CRM. In some organisations, CRM is simply a technology solution that extends separate databases and SFA tools to bridge sales and marketing functions in order to improve targeting efforts. Other organisations consider CRM as a tool specifically designed for one-to-one (Pepper et al., 1999) customer communications, a sole responsibility of service, call centres or marketing departments. But CRM is not merely technology applications for marketing, sales and service, but rather, when fully and successfully implemented, a cross-functional, customer-driven, technology-integrated business process management strategy that maximises relationships and encompasses the entire organisation (Goldenberg, 2000).

Several researchers and practitioners relate CRM with people, processes and technology. According to Injazz and Karen (2003), CRM is a 'combination of people, processes and technology that seeks to understand a company's customers; moreover, it is an integrated approach to managing relationships by focusing on customer retention and relationship development'. Hence, it is important to train the people to how to be involved with the customer directly or indirectly. Technology is certainly one of the key enabling or supporting factors in CRM, but by itself it does not constitute CRM.

2 Identification of the required technologies such as: Studying the current situation of the available technologies, identification and choosing of the mechanisms during the execution of the new strategy, defining and registering the novel all-purpose banking system, designing and implementing the new data warehouse and also contact centre. Because customer-oriented process activities are distributed across different enterprises, these processes have to be integrated among the partnering companies. Some networks also have different contact persons for a single customer. This is a typical characteristic when process integration is lacking, leading to inefficiencies and poor service quality.

Integration between the multiple touch points with customers, operational CRM, the analytical CRM, and KM tools is required in order to maximise the full power of the analytical system. Bolton (2004) suggested that implementation may fail because the organisation fails to adopt a clear strategy and also fails to make appropriate changes to its business process. Too many companies install a CRM software application in the belief that this will deliver the CRM capability the company needs. The most common fault was to focus on technology in setting out to implement CRM, to the exclusion of people, process and organisational changes required (Bolton, 2004).

A bank's touch points can include the internet, e-mail, direct mail, telemarketing operations, call centres, advertising, fax, branches and kiosks. Regardless of the channel or method used to contact the company, customers receive the same consistent and efficient service. Often, these touch points are controlled by separate information systems. CRM integrates touch points around a common view of the 
customer (Eckerson and Watson, 2001). Furthermore, it is very important to have appropriate information about customers; hence, if the bank's systems relating to various types of accounts and services did not recognise that the same customer interacted with bank in a number of ways, relating to different services of the bank, it would not be possible to take a complete view of the customer - and his/her value to the bank. The term $360^{\circ}$ customer view has been coined to refer to this need for a view of the complete set of interactions between an organisation and its customers.

3 Customer management assessment tool (CMAT): Assessments bring together a range of tools and methodologies that provide a detailed, objective, benchmarked assessment of an organisation's capability to effectively manage its customers (Stone et al., 2002). These tools and methodologies include assembling customer satisfaction measurement system (CSMS) with identification of the customer satisfaction indicator by either interviewing them or forming hubs, assembling the customer satisfaction measurement questionnaire and validating it, data analysis using structural models, interpreting the data in order to device practical plan targeted at customer satisfaction and increasing it.

4 Customer segmentation: This include segmenting customer according to demographic and other properties (commercial, industrial, import and export, manufacturing, services, public, private, permanent, temporary, big, foreign exchange or credit). The bank would need a complete view of its customers across the various channels and systems that contain their data. If the bank could track customer behaviours, then executives can have a better understanding a predictive future behaviours and customer preferences. The data and applications can help the bank manage its customer relationship to continue to grow and evolve (Dyche, 2001).

$\mathrm{Xu}$ and Walton (2005) state that CRM technologies allow the organisation to gain an insight into the behaviour of individual customers. Furthermore, it turns to target and customise marketing communication and messages. In addition, these tools generate data that support the calculation of customer lifetime value (CLV) for individual customers. This indicates that the best CRM implementations offer advantages to both the organisation and its customers.

$5 \quad$ Strategy planning for marketing and service providing for each segment of customers: CRM enables organisations to setup such strategies by managing individual customer relationships. From the service-oriented industry perspective, customer satisfaction and retention is ensured by solving customer problems quickly. Customer satisfaction is made certain by allocating, scheduling and dispatching the right people, with right parts, at the right time (Xu and Walton, 2005).

6 Calculating of the CLV: calculating the probability of either return or churn of the customer. The first step in the CRM evaluation is to determine the mission and goal of CRM. Once this is decided, the next step is to establish a CRM strategy. The purpose of this step is to gore out the principle strategic factors. After figuring out the strategic factors, the next step is to find interrelationships among CRM activities and business goals (business goals being increased profits) (Kim et al., 2003). By analysing these relationships, we can learn what should be done to achieve better 
outcomes and what perspectives are important towards achieving the outcomes. The outcome of the analysis is evaluated to identify the effectiveness of CRM. This assessment gives further insights into the CRM strategy and helps the marketer to determine the strategy of CRM (Kim et al., 2003). These banks have to create a vision based on customer, identifying customer-based processes, recognising available and required resources for extending CRM and prioritising CRM development possibilities.

7 Transforming the customer data into knowledge: Using that knowledge which transformed from data to build relationship with their customers due to create customer retention and loyalty, higher customer profitability, creation value for the customer, customisation of products and services, lower process, higher quality products and services, having integrated single view of customers, by using analytical tools (Greenberg, 2001; Newell, 2000), managing customer relationship in a single way regardless of the communicational channels, improving the effectiveness and efficiency of the processes involved in customer relationship, select and then manage the right client set, determine which service should be sold to which client, profitability and then help the bank implement this sales plan and also ability to coordinate the multi-product, multi-country relationship in real time. The above-mentioned are some of many potential benefits which are provided by CRM (Jutla et al., 2001; Foss, 2002).

Managing customer relationships effectively and efficiently boosts customer satisfaction and retention rates (Reichheld and Sasser, 1990). CRM applications help organisations assess customer loyalty and profitability on measures such as repeat purchases, dollars spent and longevity.

The implications for management of using analytical CRM lay not so much with improving operational efficiency as with other CRM systems, but rather with the empowerment of management in the strategic decision-making process. Such empowerment is achieved through customer knowledge acquisition and knowledge sharing, thus enabling the business to become a knowledge-driven organisation. To achieve this, senior management need to raise their awareness of analytical CRM and the potential benefits based on which to develop a vision focusing on gaining customer knowledge and articulating the vision throughout the organisation, whilst also being supportive to the development of such systems (Xu and Walton, 2005). The biggest threat to CRM, as suggested by Bose (2002), is managements' focus on short-run profits rather than long-term vision. The organisational strategy, structure and process may need to be transformed due to the application of analytical CRM (Xu and Walton, 2005).

\section{Conclusions}

We have investigated CRM activities in e-banking of Iranian private and public banks. Based on their organisational point of view, we proposed a framework of their CRM activities in e-banking. Consisting of three phases: first, in the communicational CRM which is the touch points of customer with bank, where the organisation recognises 
unidentified consumers as customers who are identifiable by collecting the information about them through diverse communication channels; second, an operational CRM, where the organisation builds equitable relationships through serving the customers by different services so that services can make the customer satisfied; finally, an analytical $\mathrm{CRM}$, in that the information and knowledge from the customers play the role of expanding the company's customer base through analysing the customer behaviour and the way of customer's interactions with the bank. Throughout the entire customer lifecycle, a bank is expected to measure relationship value from both perspectives and build a proper relationship positioning strategy.

After having checked the fluidity of the information, built a framework, recruited the right people and implemented the relationships, it is crucial for any organisation to continuously upgrade the data and its IT software, as well as to train people in making efficient use of the precious information gathered. Once a proper strategy is chosen, in order to collect and analyse the required customer information, it is necessary to build a customer information system for managing the relationship which consists of a customer database, a communication channel and an application for relationship management. Through the framework of CRM activities in e-banking, banks should be able to manage the entire customer relationship and use information through the cycle and make the customers loyal for more profit for the entire organisation. It is therefore essential to integrate information collected from all the distribution channels in a well-organised data mart. However, it makes little sense to do so if all the parties involved are not part of the evolution.

Although we have studied the CRM in a qualitative manner, the proposed theoretical framework may need further validation quantitatively based on real-world CRM implementation data. The concept of customer relationship activities in e-banking should be refined with detailed criteria to be applicable to other industries. Evidence from these private cases suggests that it is of major importance that the bank develops a relationship with its clients from different touch points that are based upon the weakness of the integrated and live customer's account information in public banks because of their information technology infrastructure perhaps these are one of the reasons that seems why e-banking remains so popular. Only when such a relationship has been achieved, private banks will be able to anticipate a client's need without looking as though they are desperate to cross-sell. In public banks, complementary services like cards or ATM are important because it attracts customers otherwise it has lost the competition to others.

Another challenge for the banks is to change some of its clients' behaviour towards the least expensive distribution channel, the internet. However, changing a behaviour implies changing underlying attitudes, which is clearly not an easy task. The bank is thus facing major challenges for the years to come. The CRM systems that have been implemented by many companies are dominated by operational applications contact centres, sales and marketing solutions with limited customer knowledge gained from the current CRM application. The analytical power of CRM has not been adequately perceived by many organisations. The provision of analytical CRM solutions is limited to some large organisations. It is suggested that CRM systems should enhance not only an organisation's ability to interact, attract and build one-to-one relationships with customers but also the ability to gain customer knowledge. 


\section{Further researches}

Based on conclusions and a number of issues that rose during the research process, some topics can be considered as future opportunities to be explored by interested researchers. Due to the fact that cases of this research study some CRM activities in private and public Iranian banks and how they made some core competencies for themselves. Further investigation can be performed to explore how each of these banks' CRM systems and specifically their analytical CRM, operational CRM or communicational CRM can adopt the best possible actions in each branch or the other touch points with a questionnaire and survey and as its instrument and expend measuring the objectives.

\section{Limitations}

Due to the fact that CRM systems are relatively broad topic considering limited timeframe for this study, it was impossible to cover thoroughly all the aspects of the above-mentioned subject. Therefore, the topic was narrowed down to the current one in the context of e-banking services.

This research was conducted on just four banks comprising two private banks and two public banks. As mentioned above, due to limited access to the four banks on which the current research was conducted, the interview time and number of people to interview was difficult to arrange and gain access to.

\section{References}

Bolton, M. (2004) 'Customer centric business processing', International Journal of Productivity and Performance Management, Vol. 53, No. 1, pp.44-51.

Bose, R. (2002) 'Customer relationship management: key components for IT success', Industrial Management and Data Systems, Vol. 102, No. 2, pp.89-97.

Chalmeta, R. (2006) 'Methodology for customer relationship management', Journal of Systems and Software, Vol. 79, No. 7, pp.1015-1024.

Durkin, M. (2004) 'In search of the internet-banking customer', The International Journal of Bank Marketing, Vol. 22, No. 7, pp.484-503.

Dyche, J. (2001) The CRM Handbook: A Business Guide to Customer Relationship Management, Addison-Wesley, Boston, MA.

Eckerson, W. and Watson, H. (2001) 'Harnessing customer information for strategic advantage: technical challenges and business solutions', Industry Study, p.6, The Data Warehousing Institute, Seattle, WA.

Fickel, L. (1999) 'Know your customer', CIO Magazine, Vol. 12, No. 21, pp.62-72.

Foss, B. (2002) CRM in Financial Services: A Practical Guide to Making Customer Relationship Management Work, Milford, CT.

Goldenberg, B. (2000) 'What is CRM? What is an e-customer? Why you need them now', Proceedings of DCI Customer Relationship Management Conference, 27-29 June, Boston, MA.

Greenberg, P. (2001) CRM at the Speed of Light: Capturing and Keeping Customers in Internet Real Time, McGraw-Hill Osborne Media.

Injazz, D. and Karen, P. (2003) 'Understanding customer relationship management (CRM)', Business Process Management Journal, Vol. 9, No. 5, pp.672-688. 
Jayawardhena, C. and Foley, P. (2000) 'Changes in the banking sector - the case of internet banking in the UK', Internet Research: Electronic Networking Applications and Policy, Vol. 10, No. 1, pp.19-30, available at http://www.emerald-library.com.

Jutla, D., Craig, J. and Bodorik, P. (2001) 'Enabling and measuring electronic customer relationship management readiness', Proceedings of the 34th Annual Hawaii International Conference on System Sciences Organizational Systems and Technologies Track, pp.1-10.

Keramati, A., Toufighi Zavareh, J., Ellioon, A., Moshki, H. and Sajjadiani, S. (2008) 'The adoption of customer relationship management (CRM): an empirical study on Iranian firms', International Journal of Electronic Customer Relationship Management (IJECRM), Vol. 1, No. 4, pp.354-373.

Kim, J., Suh, E. and Hwang, H. (2003) 'A model for evaluating the effectiveness of CRM using the balanced scorecard', Journal of Interactive Marketing, Vol. 17, No. 2, pp.5-19.

Kotorov, R. (2002) 'Ubiquitous organization: organizational design for e-CRM', Business Process Management Journal, Vol. 8, No. 3, pp.218-232.

Lindgreen, A. and Antioco, M. (2005) 'Customer relationship management: the case of a European bank', Marketing Intelligence \& Planning, Vol. 23, No. 2, pp.136-154.

Machauer, A. and Morgner, S. (2001) 'Segmentation of bank customers by expected benefits and attitudes', International Journal of Bank Marketing, Vol. 19, No. 1, pp.6-17.

Marshall, C. and Rossman, G.B. (1999) Designing Qualitative Research, 3rd ed., Thousand Oaks: Sage.

Miles, M.B. and Huberman, A.M. (1994) 'Qualitative data analysis: an expanded sourcebook', Sage, Thousand Oaks, USA.

Newell, F. (2000) Loyalty.com: Customer Relationship Management in the new era of Internet Marketing, McGraw-Hill, New York, NY.

Park, R. (1999) 'The global transformation of financial services', European Business Journal, Vol. 11, No. 1, pp.7-16.

Pepper, D., Rogers, M. and Dorf, B. (1999) 'Is your company ready for one-to-one marketing', Harvard Business Review, Vol. 77, No. 1, pp.151-160.

Reichheld, F.F. and Sasser, W.E. Jr. (1990) 'Zero defections: quality comes to services', Harvard Business Review, September/October, pp.105-111.

Reynolds, J. (2002) Practical Guide to CRM: Building More Profitable Customer Relationships, CMP Books, Gilroy, CA, USA.

Rollins, M. and Halinen, A. (2005) 'Customer knowledge management competence: towards a theoretical framework', in Spraque, R.H. (Ed.): IEEE - Proceedings of the 38th Annual Hawaii International Conference on System Sciences, 3-6 January, Hawaii, IEEE Computer Society, Los Alamitos, CA, pp.240-250.

Rowley, J. (2002) 'Eight questions for customer knowledge management in e-business', Journal of Knowledge Management, Vol. 6, No. 5, pp.500-511.

Stone, M., Starkey, M. and Williams, D. (2002) 'The state of customer management performance in Malaysia', Marketing Intelligence \& Planning, Vol. 20, No. 6, pp.378-385.

Tan, J.J., Titkov, L. and Poslad, S. (2003) 'Securing agent-based e-banking services', Lecture Notes in Computer Science, Vol. 2631, pp.247-258.

Wells, J.D., Fuerst, W.L. and Choobineh, J. (1999) 'Managing information technology (IT) for one-to-one customer interaction', Information and Management, Vol. 35, pp.53-62.

$\mathrm{Xu}, \mathrm{M}$. and Walton, J. (2005) 'Gaining customer knowledge through analytical CRM', Industrial Management \& Data Systems, Vol. 105, No. 7, pp.955-971.

Yin, R.K. (2003) Case Study Research: Design and Methods, 3rd ed., Sage Publications, Thousand Oaks, CA.

Zineldin, M. (1996) 'Bank strategic positioning and some determinants of bank selection', International Journal of Bank Marketing, Vol. 14, No. 6, pp.12-22. 


\section{Appendix}

\section{Interview guide}

- Name of the bank:

- Number of employees:

- Name of the respondent:

- The respondent's position:

- The first year of deploying CRM:

1 What were the initial reasons to deploy CRM systems?

2 How does the CRM help you establishing long-term relationship with your customers?

3 Can you provide some information about your CRM systems?

4 What is the role of data and database in your CRM system?

5 Regarding customer data and information: Do you collect:

6 Personal and transactional information; if yes, how; if no, why?

7 Product, service and organisational information; if yes, how; if no, why?

8 Non-transactional customer feedback information; if yes, how; if no, why?

9 How do you use the CRM? (E-commerce, e-service, self-service, multi-channel customer management)

10 How do you reach your customers (CRM touch points)? (marketing, service, advertising, sales, branches, telephone, e-commerce and m-commerce)

11 What applications do you use to analyse customers data? How do you manage customer data which in non-technological (e.g., face-to-face interaction)?

12 How do you strategically categorise your customers?

13 High lifetime value customers.

14 Early adopters of new products.

15 Customer with new ideas who find ways to improve quality or reduce cost.

16 Customers with high volume of fixed costs which enable smaller customers to become profitable.

17 How do you group your customers on the basis of historical records and other related details (i.e., customer profitability, retention, satisfaction and loyalty)? How this grouping improves bank's performance? 
18 In what other ways do you categorise your customers?

- Revenue side (e.g., usage intensity and behaviour)?

- Cost side (e.g., products purchased, channel used, and intensity of customer care usage and service levels)?

19 Do you regularly monitor and analyse customers' behaviours and characteristics (i.e., customers' details, historical records, demographics, preferences, life styles and personal habits)?

20 How do you use analytical CRM to identify and prevent your defecting customers to switch to competitors? What about your prospective customers?

21 How do you categorise your profitable customers? Do you consider relationship volume (sum of customers' yearly average deposit and loan balances) and relationship profitability (relationship revenue minus relationship costs over a fiscal year) in categorising your customers? If yes, how? How do you manage different categories? How does this affect the bank's goals?

22 How does the internet banking empowering your bank to target, reach and overall retain core customers?

23 Do you provide those core customers with additional personalised services and extra control over their interactions while you know they are ready to pay additional charges for those services? If yes, how? If no, why?

24 Do you explicitly recognise customer acquisition; retention; development and cost management in your marketing planning activity and use this to steer customer management planning?

25 Can you determine the worth of INDIVIDUAL customers; combining sales margin; sale and marketing cost; management cost; logistics and service, etc.?

26 Does the way in which customers and prospects are segmented in planning activity match closely and usefully with the way in which the organisation actually does business at customer interfaces?

27 Do formal contact strategies exist for each of your identified PROSPECT segments?

28 Is sufficient history of consistent customer transaction data available in a form which allows detailed analysis?

29 Do you regularly measure the retention rates of each segment?

30 Do plan your customer development activity clearly understanding those customers that you actively want to develop and those you positively do not want to or need to develop?

31 Do key account plans exist for your highest value customers reflecting your relationship/development objectives?

32 Do you understand what the main drivers of loyalty are for each of your customer segments?

33 Does the organisational structure facilitate the smooth transition from the creation of new customer strategies and approaches to their implementation? 
34 Do you have a comprehensive and accessible customer information plan covering information value; acquisition priorities; information management and usage?

35 Is the customer database accessible to all staff whose role involves significant customer contact in a way that matches their needs?

36 Have you adopted a continuous improvement process for evolving your customer management activity?

37 Do you recognise the potential length of lifetime of new customers as well as their short term value when allocating marketing budget and priorities?

38 Do you have clearly communicated performance standards in place for enquiry handling?

39 Do you have a prioritised structure for capturing important customer information first which is supported by your customer management systems?

40 Do you apply formal key account management (KAM) principles for your most important accounts?

41 Do you actively use the information that you collect on customers to achieve ever improving management of them?

42 Do you have a no blame culture and appropriate targeting/reporting that encourages staff to record all complaints as a positive means of improving customer service?

43 Do you have clear targets for resolution time of complaints?

44 Do you have a clear top level set of measures that define customer management performance for your organisation in terms of the retention, efficiency, acquisition and profitability (REAP) areas?

45 Do you have formal key performance indicators defined and used for all campaigns so that they can be compared?

46 Do you understand the relative costs of servicing customers through the various channels?

47 Do sales, service and marketing individuals have relevant customer management measures defined in terms of acquisition retention and development (REAP)?

48 Does your customer research capture in-depth customer satisfaction information for each of the key elements of your product/service proposition? 